DOI:

Роксолана Придатко, магістр кафедри початкової та дошкільної освіти Львівського національного університету імені Івана Франка

\title{
СОЦАЛЬНО-КОМУНІКАТИВНА КОМПЕТЕНТНІСТЬ ЯК СКЛАДОВА ПРОФЕСІЙНОСТІ ВИХОВАТЕЛЯ ЗАКЛАДУ ДОШКІЛЬНОЇ ОСВІТИ
}

Стаття присвячена теоретичному узагальненні наукової проблеми формування сочіальнокомунікативної компетениії вихователя закладу дошкільної освіти. Соціально-комунікативна компетентність вихователя закладу дошкільної освіти розглядається як здатність педагога реально оцінювати навколишню дійсність, зрозуміти основні закономірності соціальної ситуації, знайти інформацію в невизначених умовах і впевнено будувати свою поведінку для досягнення балансу між власними потребами й очікуваннями, сенсом життя і вимогами соціальної дійсності; вміння здійснювати відповідні комунікативні дї̈ в певному колі ситуаџій міжособистісної взаємодї та фахові знання закономірностей і форм спілкування й правил поведінки в різноманітних ситуаціях.

Ключові слова: соціально-комунікативна компетентність; вихователь ЗДО; професійність; сочіальна компетентність.

Jim. 11.

Roksolana Prydatko, Master Student of the Primary and Preschool Education Department Lviv Ivan Franko National University

\section{THESOCIAL-COMMUNICATIVECOMPETENCEASACOMPONENTOFTHE PROFESSIONALISMOFTHE EDUCATOROFPRESCHOOLEDUCATIONALESTABLISHMENT}

The article is devoted to the theoretical generalization of the scientific problem of formation of social and communicative competence of the teacher of the institution of pre-school education. It is summarized that the conditions for the successful formation of professional competence are the formation of the outlook and orientation of the individual, on the basis of which the acquisition of knowledge and skills takes place; the development of professional abilities and professionally significant personality traits in the context of acquiring pedagogical experience. The professional competence of the educator is a necessary condition for improving the quality of the pedagogical process.

The social and communicative competence of the teacher of the institution of preschool education is considered as the teacher's ability to really assess the surrounding reality, to understand the basic laws of the social situation, to find information in uncertain conditions and to confidently build their behavior in order to achieve a balance between their own needs and expectations, the meaning of life, and the requirements of social reality; the ability to carry out the appropriate communicative actions in a certain range of situations of interpersonal interaction and professional knowledge of patterns and forms of communication and rules of conduct in various situations.

The introduction of social and communicative competence into the educational process of modern preschool education is necessary for the full development of a child of preschool age, the formation of the abilities and capabilities necessary for solving various life problems independently.

Keywords: a social and communicative competence; a teacher of the preschool education; professionalism; a social competence.

П остановка проблеми. Безперечно, ефективність роботи освітніх навчальних закладів залежить не лише від програм навчання і виховання, а й від особистості педагога, його взаємин із дітьми та професіоналізму. Кожен талановитий висококваліфікований, вдумливий педагог поєднує у своїй практиці загальнотеоретичні досягнення педагогіки, власний досвід, особистісні переваги та особливості дітей, з якими він працює. Жодна найдосконаліша теорія не може дати вичерпної відповіді, яким бути педагогу, але вона $є$ основою, на якуповинен опиратися навіть найобдарованіший із них.

(C) Р. Придатко, 2018
Сучасний вихователь - це кваліфікований фахівець, який працює в системі дошкільної освіти, володіє педагогічними технологіями та знаннями, що відповідають новим суспільним цілям та рівню розвитку науки про дитину, від якого залежить ефективність діяльності закладу дошкільної освіти.

Особливості формування соціальнокомунікативної компетентності вихователів дошкільного навчального закладу $є$ надзвичайно актуальною проблемою, оскільки жодна інша професія не ставить таких вимог до людини, як професія педагога, вчителя, вихователя.

Мета статті - полягає у теоретичному 


\section{СОЦІЛЬНО-КОМУНІКАТИВНАКОМПЕТЕНТНІСТЬ ЯКСКЛАДОВАПРОФЕСІЙНОСТІ ВИХОВАТЕЛЯ ЗАКЛАДУ ДОШКІЛЬНОӤ ОСВІТИ}

узагальненні наукової проблеми формування соціально-комунікативної компетенції вихователя закладу дошкільної освіти.

Аналіз останніх досліджень і публікацій. Комунікативні здібності особистості досліджували Л. Бірюк, Н. Вітюк, В. Гаркуша, П. Гончарук, Л. Карамушка, Я. Коломінський, С. Максименко, К. Роджерс, Л. Савенкова, М. Савчин, Я. Шкурко та ін.; теорію і практику формування комунікативної компетенції - В. Андрієвська, М. Вашуленко, О. Власова, А. Волинець, Н. ДзюбишинаМельник, А. Коваленко, А. Пасічник, І. Товкач, В. Федоренко, В. Федорчук, В. Черевко, Т. Щербан та ін.; комунікативні навички і вміння С. Бондаренко, О. Винославська, В. Каплінський, В. Мотирко, В. Семиченко, Т. Шепеленко та ін.; комунікативний потенціал особистості в соціокультурному аспекті - Н. Гавриш, Т. Піроженко, С. Терещук, Т. Яценко та ін. Феномен соціально-комунікативної компетенції дошкільників $\epsilon$ предметом досліджень М. Айзенбарт, А. Богуш, Ж. Горіної, Л. Калмикової та ін.

Дослідники І. Звєрєва, А. Капська, А. Мудрик, I. Печенко розробили концепції соціалізації особистості; О. Кононко, С. Литвиненко, I. Рогальська аналізували результативне формування соціальних уявлень молодої особистості; психологи В. Слот та Х. Спанярд висвітлили модель соціальної компетенції; вчений В. Радул визначили структуру та зміст соціальної зрілості.

Зауважимо, що комунікативні здібності вчені О. Леонтьєв, Л. Петровська розглядають як основу для досягнення високих результатів в особистісному розвитку та навчальній діяльності, О. Леонтьєв, Е. Роджерс як чинник успішної самореалізації, Н. Вітюк, Н. Волкова , Т. Зав’язун, Г. Данченко як складову комунікативної компетентності.

Теоретичному з'ясуванню змісту дефініцій “соціальна компетенція” присвячені численні дослідження таких зарубіжних та вітчизняних науковців, як І. Зимняя, Л. Коломійченко, В. Куніцина та ін.

Виклад основного матеріалу. Проаналізувавши діяльність педагога здітьми дошкільного віку, можна зазначити, що вихователь - це, насамперед: добра і чуйна людина, особистість, що багато знає, вміє, цікаво навчає; любить, розуміє і поважає особистість дитини; має професійну освіту; володіє педагогічною майстерністю; прагне до самовдосконалення; вміє спілкуватись 3 дітьми, враховуючи їх особливості як психолог.

В. Сухомлинський відзначав, що “виховання - це людські стосунки. Хороший педагог - це, насамперед, людина, що любить дітей, знаходить радість у спілкуванні з ними, вірить у те, що кожна дитина може стати доброю людиною, вміє дружити 3 дітьми, бере близько до серця дитячі радощі і прикрощі, знає душу дитини, ніколи не забуває, що він сам був дитиною" [11]. Отже, сучасний педагог дошкільної освіти має бути саме таким. Бути не тільки вчителем для дошкільників, а й людиною з багатою духовністю, тактовною, гуманною, доброзичливою.

Вимоги до професійної діяльності вихователя, до його майстерності - це сукупність знань, умінь та навичок, а також професійних якостей, що у сукупності визначають успішність та ефективність педагогічної діяльності.

Комунікація $є$ однією 3 важливих форм активності особистості, без якої неможливі їі діяльність, пізнання, рефлексія тощо. Цей процес характеризується взаємодією між людьми. Загальновизнано, що продуктивність пізнавальної, мисленнєвої діяльності, загальна життєздатність людини значною мірою залежать від іï здатності до спілкування, від рівня сформованості комунікативної компетенції.

Під час спілкування з дошкільниками потрібно дотримуватися таких принципів (за І. Луценко): 1) гуманізація комунікативних настанов педагога (передбачає повагу до дитиниспіврозмовника, іiі особистості, інтересів, уподобань); 2) задоволення потреб дітей y спілкуванні, розвиток мотивів спілкування $з$ дорослими ц̌ однолітками (орієнтований на реалізацію особистісного підходу до дитини); 3) приклад товариськості й рівноправності, конструктивна позиція у спілкуванні з дітьми (успішна взаємодія з дітьми залежить від товариськості педагога); 4) діалогічна орієнтація у спілкуванні $і$ діалогічність мовлення педагога, добір оптантивних мовленнєвих форм (передбачає рівноправність позицій педагога і дитини у спільному пошуку правильної відповіді, способу розв'язання комунікативної проблеми, навчання дітей відстоювати свої погляди, сумніватись у готових відповідях, формулювати проблемно-пошукові запитання); 5) дотримання професійної та мовленнєвої етики (встановлення емоційної довіри і підтримка позитивної атмосфери спілкування визначаються віковими особливостями мовленнєвої взаємодії 3 дошкільниками); 6) досягнення розвивального ефекту в проиесі мовленнєвого спілкування вихователя 3 дітьми (передбачає досягнення комунікативного успіху, позитивного педагогічного результату) [7]. 


\section{СОЦІАЛЬНО-КОМУНІКАТИВНА КОМПЕТЕНТНІСТЬ ЯКСКЛАДОВАПРОФЕСІЙНОСТІ ВИХОВАТЕЛЯ ЗАКЛАДУ ДОШКІЛЬНОЇ ОСВІТИ}

Соціальна компетенція особистості включає насамперед іiї бажання й уміння спілкуватися 3 іншими людьми, наявність позитивної мотивації у стосунках із ними, впевненість у собі, емпатію $\mathrm{i}$ здатність керувати соціальними ситуаціями та використовувати ефективні стратегії для досягнення комунікативних цілей. Для реалізації останніх необхідно володіти певним комунікативним досвідом, який передбачає передовсім способи взаємодії з людьми, що нас оточують, а також співробітництво у груповому спілкуванні, навички роботи в колективі, здатність брати на себе відповідальність і долати конфлікти.

Так, у тлумаченні I. Зимньої [4], соціальна компетенція постає як ключова, оскільки забезпечує нормальну життєдіяльність особистості в соціумі і $є$ цілісним результатом іiі професійної освіти.

Наголосимо, що соціальна компетенція перебуває у тісному взаємозв'язку 3 комунікативною, оскільки проявляється у всіх життєвих сферах людини. Поняття “комунікативна компетенція" ввів до наукового вжитку американський лінгвіст Д. Хаймз (у 1972 р.) на противагу теорії мовної компетенції Н. Хомського. Теорія і практика формування комунікативної компетенції розроблялася науковцями Г. Андрєєвою, І. Бехом [1], та ін.

Зокрема, проблеми комунікативної компетенції та окремих її компонентів перебувають у центрі уваги таких українських науковців, як А. Богуш [2], М. Вашуленко, М. Пентилюк та ін.

Сучасні вітчизняні ізарубіжні дослідники (І. Бім, I. Зимняя, Л. Петровська, у своїх численних наукових працях тлумачать комунікативну компетенцію як: 1) сукупність знань про систему мови та їі одиниці, їх побудову і функціонування в мові, про способи формулювання думок рідною (іноземною) мовою і розуміння суджень інших, про національно-культурні особливості носіїв мови, про специфіку різних типів дискурсів; 2) здатність мовця вербальними засобами здійснювати спілкування в різних видах мовленнєвої діяльності відповідно до поставлених комунікативних завдань, розуміти, інтерпретувати і формулювати зв'язні висловлювання.

Комунікативна компетенція максимально підкреслює здатність людини до спілкування. Адже суть цієї компетенції полягає у вмінні особистості налагоджувати активну взаємодію, чи комунікацію, з іншими [4].

С. Литвиненко стверджує, що комунікативна компетенція забезпечує комплексне застосування мовних і немовних засобів із метою комунікації в конкретних соціально-побугових ситуаціях, уміння орієнтуватися в них, а також ініціативність спілкування [6].

На думку А. Богуш, комунікативна компетенція - це обізнаність людини, певна система знань, практичних мовленнєвих умінь і навичок, мовленнєвих здібностей [2].

За А. Мудрик [8], яка активно опрацьовувала проблеми міжособистісного спілкування, комунікативна компетенція - це сукупність мовної, мовленнєвої та соціокультурної складових, оволодіння всіма видами мовленнєвої діяльності і культурою мовлення; здатність педагога розв'язувати мовними засобами певні комунікативні завдання в різних сферах і ситуаціях спілкування.

Фахівці Дж. Ван Ек і Дж. Трім визначають шість компонент комунікативної компетенції (лінгвістичну, соціолінгвістичну, дискурсивну, соціокультурну, сочіальну та стратегічну) [10].

Зі свого боку, дослідники М. Канале і М. Свейн запропонували власну структуру комунікативної компетенції, яка включає граматичну (пов' язана 3 синтаксисом), соціолінгвістичну (стосується соціальної доцільності), дискурсивну $i$ стратегічну (орієнтована на прагматичну функцію комунікації) компоненти [10].

Складові комунікативної компетенції досить різноманітні. Подаємо стислий перелік ії найбільш досліджених компонент, що включає: 1) знання особливостей і проблем тих осіб, із якими потрібно спілкуватися; 2) володіння відповідними комунікативними технологіями; 3 ) вміння аналізувати жести, міміку та інтонації співрозмовника; 4) обізнаність 3 азами ораторського мистецтва, їх практичне застосування; 5) здатність запобігати конфліктам та врегулювати ті, що виникли; 6) багатий словниковий запас; 7) мистецтво емпатії; 8) дотримання норм етики й етикету; 9) деякі акторські здібності; 10) навички активного слухання; 11) грамотність і стилістична внормованість писемного мовлення; 12) розвинене усне мовлення, його впевнена інтонація та відповідне емоційно-ситуативне забарвлення; 13) вміння аргументувати власні погляди та відстоювати їх. Така структура комунікативної компетенції, як бачимо, має універсальний характер, оскільки увиразнює більшість значущих аспектів продуктивного міжособистісного спілкування [9].

Значення соціально-комунікативних компетенцій особистості відзначають у своїх працях Н. Бібік [4], О. Овчарук [4] та ін.

Соціально-комунікативна компетенція - це 


\section{СОЦАЛЬНО-КОМУНІКАТИВНА КОМПЕТЕНТНІСТЬ ЯКСКЛАДОВАПРОФЕСІЙНОСТІ}

ВИХОВАТЕЛЯ ЗАКЛАДУ ДОШКІЛЬНОӦ ОСВІТИ

здатність людини реалізовувати власні потреби і цілі шляхом створення партнерських стосунків 3 іншими особами згідно з їхніми очікуваннями, потребами і цілями в межах суспільно прийнятної поведінки та завдяки ефективній комунікації [9].

Науковці (Н. Бібік, Л. Ващенко, О. Локшина, О. Овчарук та ін. [4]) стверджують, що соціальнокомунікативна компетенція особистості - це базова інтегральна характеристика, яка відображає рівень уміння людини взаємодіяти, чи контактувати, з іншими особами; забезпечує оволодіння соціальною реальністю за допомогою комунікативних механізмів і дає можливість ефективно впливати на свою поведінку та поведінку інших у середовищі, де відбувається спілкування.

I. Гушлевська підкреслює, що упровадження соціально-комунікативної компетенції до виховного процесу сучасної дошкільної освіти $€$ необхідним для повноцінного розвитку дитини дошкільного віку, формування у неї здібностей та можливостей, необхідних для самостійного розв'язання різних життєвих проблем; здатності до співпереживання; готовності до вільного гуманістично орієнтованого вибору, індивідуального інтелектуального зусилля і самостійної, компетентної та відповідальної дії в політичному, економічному, професійному і культурному житті; поваги до себе й інших; терпимості до представників інших національностей; незалежності в думках та відкритості для іншого погляду й несподіваної думки [3].

Висновок. Отже, умовами успішного формування професійної компетентності $€$ формування світогляду та спрямованості особистості, на основі яких відбувається засвоєння знань і умінь; розвиток професійних здібностей та професійно значущих рис особистості в контексті набуття педагогічного досвіду. Професійна компетентність вихователя - це необхідна умова підвищення якості педагогічного процесу.

Соціально-комунікативна компетенція вихователя - це його здатність реально оцінювати навколишню дійсність на базі особистих знань про неї, які дають змогу зрозуміти основну закономірність соціальної ситуації, знайти інформацію в невизначених умовах і впевнено будувати свою поведінку для досягнення балансу між власними потребами й очікуваннями, сенсом життя і вимогами соціальної дійсності; вміння здійснювати відповідні комунікативні дії в певному колі ситуацій міжособистісної взаємодії та фахові знання закономірностей і форм спілкування й правил поведінки в різноманітних ситуаціях.

\section{ЛІТЕРАТУРА}

1. Бех І. Д. Виховання особистості: у 2 кн. / І. Д. Бех. - Кн. 2: Особистісно орієнтований підхід: науково-практичні засади. - К.: Либідь, 2003. - $344 \mathrm{c}$.

2. Богуш А. М. Наступність, перспективність, спадкоємність - складові неперервної освіти / А. М. Богуш // Дошкільне виховання. - 2001. № 11. - С. 11-12.

3. Гушлевська I. Поняття компетентності у вітчизняній та зарубіжній педагогіці / I. Гушлевська // Шлях освіти. - 2004. - № 3. C. $22-24$

4. Компетентнісний підхід у сучасній освіті: світовий досвід та українські перспективи [бібліотека з освітньої політики] / Н. М. Бібік, Л. С. Ващенко, О. І. Локшина та ін.; за ред. О. В. Овчарук. - К.: КІС, 2004. - 112 с.

5. Комунікативна компетенція [Електронний pecypc]. - Режим доступу: http: // wjournal.com.ua/ komunikativna-kompetencija.html.

6. Литвиненко С. А. Дитина і середовище: проблеми взаємодіi/С. А. Литвиненко,В.М.Ямницький // Гуманітарний вісник Переяслав-Хмельницького державного педагогічного університету ор. Г. Сковороди: Науково-теоретичний часопис. - Переяслав-Хмельницький, 2003. - С. 215-220.

7. Луценко I. О. Готуємось до мовленнєвого спілкування $з$ дошкільниками: навч. посіб. [Електронний ресурс] / І. О. Луценко; М-во освіти і науки України, Нац. пед. ун-т імені М. П. Драгоманова. - К.: НПУ, 2001. - 96 с. - Режим доступу: http:/catalog.odnb.odessa.ua/ opac/index.php?url=/notices/index/IdNotice:5487/ Source:default.

8. Мудрик А. Социализация человека как проблема / А. Мудрик // Социальная педагогика. - 2005. - № 4. - C. 47-57.

9. Сарапулова Є. Г. Самопізнання та етика спілкування як засоби формування комунікативних вмінь у представників молодого покоління / Є. Г. Сарапулова, Т. Д. Панченко // Педагогіка толерантності. - 2008. - № (45). - С. 57-65.

10. Скрипченко О. В. Вікова та педагогічна психологія: навч. посіб. / О. В. Скрипченко, Л. В. Долинська, 3. В. Огороднійчук та ін. - К.: Просвіта, 2001. - 416 с.

11. Сухомлинський В. О. Серце віддаю дітям / В. О. Сухомлинський // Сухомлинський В. О. Вибрані твори: у 5-ти т. / В. О. Сухомлинський. Т. 3. - К.: Рад. Школа, 1977. - 670 с.

\section{REFERENCES}

1. Bekh, I. D. (2003). Vykhovannia osobystosti: u $2 \mathrm{kn}$. [Education of the person: in two books.]. The 


\section{СОЦІАЬНО-КОМУНІКАТИВНАКОМПЕТЕНТНІСТЬ ЯКСКЛАДОВАПРОФЕСЙННОСТ ВИХОВАТЕЛЯ ЗАКЛАДУ ДОШКІЛЬНОЇ ОСВІТИ}

second book: A personality-oriented approach: the scientific and practical principles. Kyiv: Lybid, 344 p. [in Ukrainian].

2. Bohush, A. M. (2001). Nastupnist, perspektyvnist, spadkoiemnist-skladovi neperervnoi osvity[Continuity, perspective, and succession are the constituents of the continuous education]. Preschool education, no. 11, pp. 11-12. [in Ukrainian].

3. Hushlevska, I. (2004). Poniattia kompetentnosti u vitchyznianii ta zarubizhnii pedahohitsi [The concept of competence in the domestic and foreign Pedagogy]. School education, no.3, pp. 22-24. [in Ukrainian].

4. Bibik, N. M., Vashchenko, L. S., Lokshyna, O. I. et al; (Ed.). O. V. Ovcharuk (2004). Kompetentnisnyi pidkhid u suchasnii osviti: svitovyi dosvid ta ukrainski perspektyvy [A competency approach in the modern education: the world experience and Ukrainian perspectives]. Kyiv: KIS, 112 p. [in Ukrainian].

5. Komunikatyvna kompetentsiia [Communicative competence]. [Electronic resource]. Available at: http: // wjournal.com.ua/komunikativna-kompetencija. html. [in Ukrainian].

6. Lytvynenko, S. A. \&. Yamnytskyi, V. M. (2003). Dytyna i seredovyshche: problemy vzaiemodii [The child and the environment: the problems of interaction]. Humanitarian Herald of PereyaslavKhmelnytskiy Hryhoriy Skovoroda State Pedagogical University: Scientific and Theoretical Journal.
Pereiaslav-Khmelnytskyi, pp. 215-220. [in Ukrainian].

7. Lutsenko, I. O. (2001). Hotuiemos do movlennievoho spilkuvannia z doshkilnykamy: navch. posib. [We are preparing for speech communication with preschoolers]. [Electronic resource]. Ministry of Education and Science of Ukraine. National Academy of Sciences of Ukraine, Mykhaylo Drahomanov National Pedagogical University. Kyiv: NPU, 96 p. Available at: http://catalog. odnb. odessa.ua/opac/index.php?url=/notices/index/ IdNotice:5487/Source:default. [in Ukrainian].

8. Mudrik, A. (2005). Sotsializatsiya cheloveka kak problema [Socialization of person as a problem]. Social pedagogy, no.4, pp.47-57. [in Russian].

9. Sarapulova, Ye. H. \& Panchenko, T. D. (2008). Samopiznannia ta etyka spilkuvannia yak zasoby formuvannia komunikatyvnykh vmin u predstavnykiv molodoho pokolinnia [The self-knowledge and ethics of communication as a means of forming the communicative skills among the representatives of the young generation]. Pedagogy of Tolerance, no.(45), pp. 57-65. [in Ukrainian].

10. Skrypchenko, O. V. \& Ohorodniichuk, Z. V. et al., (2001). Vikova ta pedahohichna psykholohiia: navch. posib. [Age and Pedagogical Psychology: Tutor manual]. Kyiv: Prosvita, 416 p. [in Ukrainian].

11. Sukhomlynskyi, V. O. (1977). Sertse viddaiu ditiam [I give my heart to children]. Selected works in 5 volumes.Vol. 3. Kyiv: Rad. Shkola, 670 p. [in Ukrainian].

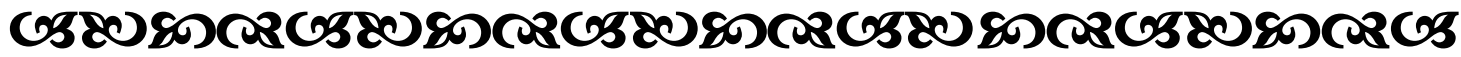

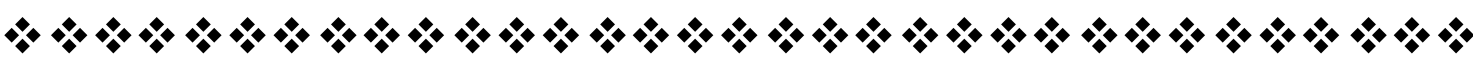

"Нехай статечність учителя не супроводжується грубістю, ласкавість слабкістю; щоб не привернути до себе периим шляхом ненависті, а другим - презирства. Нехай частіше говорить з учнями про хорошу поведінку, бо чим частіші будуть умовляння, тим рідше знадобляться поқарання. Нехай не буде запальним $i$ не поступається там, де потрібна суворість... Нехай прикладе зусилля сказати, повчаючи учнів, щодня щось таке, що змогло бу них назавжди залишитися в пам'яті".

Квінтиліан

найвідоміший із римсьқих педагогів, ритор

"Хто бажає, щоб народ був щасливим $і$ виховувався успішно, той повинен визнати першою і необхідною умовою досягнення цієї мети виховання й освіту вчителів, а тақож їх стан, який відповідав би їхньому важливому обов'язку... Якщо ви турбуєтеся про своїх дітей, потурбуйтеся про прочвітання тих, кому довірено їхвиховання".

Адольбб Dістервег німеиький педагог

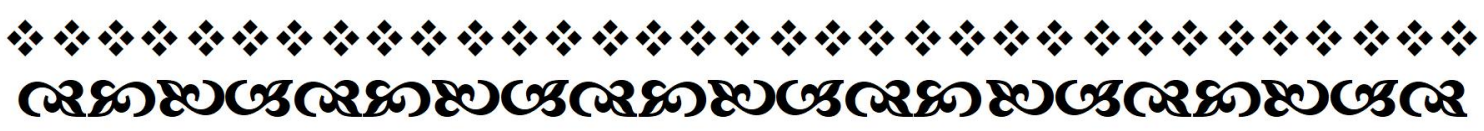

